\title{
The study of maternal outcome of early onset severe pre eclampsia with expectant management
}

\author{
Manjusha Viswanathan*, Suja Daniel
}

Department of Obstetrics and Gynecology, Sree Gokulam Medical College and Research Foundation, Venjaramoodu, Trivandrum- 695607, Kerala, India

Received: 11 December 2013

Accepted: 15 December 2013

\section{*Correspondence:}

Dr. Manjusha Viswanathan,

E-mail: manjuvishy@yahoo.com

(C) 2014 Viswanathan M et al. This is an open-access article distributed under the terms of the Creative Commons Attribution Non-Commercial License, which permits unrestricted non-commercial use, distribution, and reproduction in any medium, provided the original work is properly cited.

\begin{abstract}
Background: Hypertensive disorders in pregnancy forms one of the deadly triads along with hemorrhage and jaundice which result in maternal death. The present management is termination of pregnancy which causes high neonatal morbidity. Hence the study is done to assess the outcome of prolongation of pregnancy. The aim of this study was to evaluate the safety and outcome of women undergoing expectant management of early onset severe pre eclampsia.

Methods: Prospective case series extending over 1 year in a tertiary care teaching hospital. All women with singleton pregnancy presenting with severe pre eclampsia with gestational age (GA) less than 34 weeks were included in the study. All patients with major maternal or fetal complications were excluded. The included patients were admitted in the intensive care labor ward for non-invasive monitoring of mother. The patients were treated with anti hypertensives, $\beta$ methasone injection and prophylactic magnesium sulphate when required. They were monitored with regular 4 hrly BP charting, lab investigations and fetal monitoring. The data obtained were expressed as means with standard deviation and median with range. The difference in mean were analysed, the chi-square test was applied to quantitative variables.

Results: In women recruited in the study after expectant management the mean and median number of days gained by women ante partum was 16.7 and 14.2 days respectively. It is seen that most of the complications occurs after 30 weeks of gestation. There was no death reported.

Conclusions: The results of the study showed that it was best to put the women presenting with early onset severe pre eclampsia in expectant management and deliver her after 34 weeks. This was achieved with no increased mortality or morbidity to mother.
\end{abstract}

Keywords: Severe pre-eclampsia (SPE), Eclampsia, HELLP syndrome

\section{INTRODUCTION}

The incidence of hypertensive disorders of pregnancy is $8 \%$ and this forms one of the deadly triads along with hemorrhage and jaundice which result in maternal death. According to WHO severe preeclampsia accounts for $16.1 \%$ of maternal deaths in developed countries over the past 2 decades. ${ }^{1}$

\section{Objective of study}

To evaluate safety and outcome of women undergoing expectant management of early onset severe preeclampsia

\section{Design}

Prospective case series over 1 year period. 


\section{Setting}

Tertiary teaching hospital

\section{METHODS}

\section{Inclusion criteria}

Over one year period all women with singleton pregnancies and early onset severe pre eclampsia where both mother and fetus were otherwise stable were included in the study.

\section{Exclusion criteria}

Any major maternal or fetal complications.

The definition of hypertension and proteinuria were those accepted by the international society for the study of hypertension in pregnancy. The women thus identified were admitted into the intensive care labor ward for noninvasive monitoring of maternal status.

\section{Assessment of maternal and fetal status}

Gestation was estimated by last menstrual period, obstetric USG or both.

Maternal monitoring was done by 4 hourly BP chart, urine protein examination daily and clinical examination daily, and other relevant investigations every 2 days.

The fetus was monitored by daily fetal monitoring, NST on alternate days, USG with Doppler and BPP every week.

Table 1: Investigations.

\begin{tabular}{|c|c|c|c|}
\hline Maternal & & Fetal & \\
\hline BP chart & $\begin{array}{l}4 \\
\text { hourly }\end{array}$ & $\begin{array}{l}\text { Fetal } \\
\text { movement } \\
\text { count }\end{array}$ & Daily \\
\hline $\begin{array}{l}\text { Urine } \\
\text { protein } \\
\text { Estimation }\end{array}$ & Daily & $\begin{array}{l}\text { Non stress } \\
\text { test }\end{array}$ & $\begin{array}{l}\text { Every } \\
48 \text { hrs }\end{array}$ \\
\hline $\begin{array}{l}\text { Clinical } \\
\text { examination }\end{array}$ & Daily & $\begin{array}{l}\text { USG with } \\
\text { BPP }\end{array}$ & $\begin{array}{l}\text { Every } \\
48 \text { hrs }\end{array}$ \\
\hline $\begin{array}{l}\text { Liver } \\
\text { function test }\end{array}$ & $\begin{array}{l}\text { Every } \\
48 \mathrm{hrs}\end{array}$ & $\begin{array}{l}\text { USG with } \\
\text { Doppler }\end{array}$ & $\begin{array}{l}\text { Every } \\
\text { week }\end{array}$ \\
\hline $\begin{array}{l}\text { Renal } \\
\text { function test }\end{array}$ & $\begin{array}{l}\text { Every } \\
48 \text { hrs }\end{array}$ & & \\
\hline $\begin{array}{l}\text { Platelet } \\
\text { count }\end{array}$ & $\begin{array}{l}\text { Every } \\
48 \mathrm{hrs}\end{array}$ & & \\
\hline
\end{tabular}

Maternal BP was controlled by anti hypertensives $\alpha$ methyl dopa, nifedipine and atenolol in step wise approach. Magnesium sulphate was given prophylactically to all patients. Betnasol was also administered. Termination of pregnancy was done in event of any adverse maternal condition.

Table 2: Drugs given for treatment.

\begin{tabular}{|ll|}
\hline Drug & Dose \\
\hline$\alpha$-Methyl dopa & $\begin{array}{l}250-500 \mathrm{mg} \mathrm{3-4} \mathrm{times} \mathrm{daily} \\
\text { orally }\end{array}$ \\
\hline Nifedipine & $10 \mathrm{mg} \mathrm{3-4} \mathrm{times} \mathrm{daily} \mathrm{orally}$ \\
\hline Atenolol & $25 \mathrm{mg}$ once or twice daily orally \\
\hline Inj Betnasol & $12 \mathrm{mg}$ daily for 2 days \\
\hline Inj Magnesium sulfate & \\
\hline
\end{tabular}

The data obtained were expressed as mean with standard deviation and median with range. Difference in mean were analysed the chi square test was applied to quantitative variables. $P$ value $<0.05$ was taken as significant. The study was compared for analysis with other studies.

\section{RESULTS}

During 1 year period 17585 women delivered in the hospital.

Table 3: Women delivered during 1 year period.

\begin{tabular}{|ll|}
\hline Parameter & \\
\hline No. of deliveries & 17585 \\
\hline Cases GHT & $1066(6 \%)$ \\
\hline Cases SPE & $413(2 \%)$ \\
\hline Cases in study & 105 \\
\hline
\end{tabular}

The youngest woman enrolled in the study was of $18 \mathrm{yrs}$ and oldest $37 \mathrm{yrs}$.

Table 4: Age ratio of primi and multi gravida.

\begin{tabular}{|lllll|}
\hline $\begin{array}{l}\text { \% of total } \\
\text { deliveries }\end{array}$ & $\begin{array}{l}\text { Mean } \\
\text { age }\end{array}$ & $\begin{array}{l}\text { SD } \\
\text { ratio }\end{array}$ & $\begin{array}{l}\text { \% of } \\
\text { SPE }\end{array}$ \\
\hline Primi & 61.9 & 24.8 & 3.7 & 73.3 \\
\hline Multi & 38.1 & 26.1 & 4.5 & 26.7 \\
\hline
\end{tabular}

Mean age of admission of primi was 24.8 with SD of 3.7. The mean age of multi was 26.1 with SD of 4.5 . The primi accounted for $61.9 \%$ and multi $38.1 \%$ of the total. The chi-square test applied $X^{2}=5.81 \mathrm{p}<0.05$, the observed difference was found to be significant. The nulliparous women were $73.3 \%$ and multiparous $26.7 \%\left(\mathrm{X}^{2}=22.86\right.$, $\mathrm{P}<0.001)$. The finding was significant statistically.

In women recruited in the study after expectant management the mean and median number of days gained by women antepartum was 16.7 and 14.2 days respectively. 
Table 5: Gestational age at entry and prolongation of pregnancy.

\begin{tabular}{|llllll|}
\hline GA at entry & $\mathbf{N}$ & Mean & SD & Median & Range \\
\hline$\leq 25$ & 4 & 30.8 & 34.1 & 24.7 & $1-74$ \\
\hline 26 & 1 & - & - & - & - \\
\hline 27 & 2 & 38 & 38.1 & 38 & $11-65$ \\
\hline 28 & 5 & 11 & 9 & 8 & $3-26$ \\
\hline 29 & 9 & 16 & 15.3 & 12 & $2-44$ \\
\hline 30 & 15 & 11.7 & 10.4 & 10 & $0-25$ \\
\hline 31 & 8 & 13.4 & 12.1 & 12 & $2-37$ \\
\hline 32 & 25 & 13.6 & 8.1 & 14 & $0-34$ \\
\hline 33 & 18 & 10 & 10.2 & 5 & $0-30$ \\
\hline$\geq 34$ & 18 & 5.8 & 5.7 & 5 & $1-13$ \\
\hline
\end{tabular}

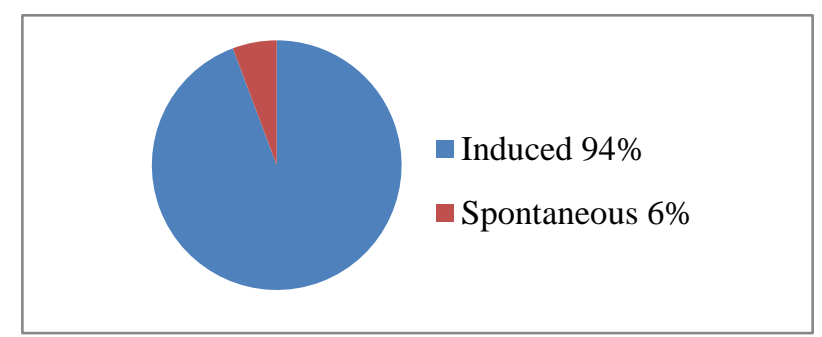

Figure 1: Relationship between spontaneous and induced labor.

Only 5\% ( $\mathrm{n}=6)$ went in for spontaneous delivery. $95 \%$ were induced with dinoprost gel $(n=99)$.

Of these $15 \%(n=16)$ the fetus had died in utero. There were 11 cases $(10 \%)$ still birth and 78 live born Vaginal delivery was achieved in 90 cases $(85.5 \%)$ and rest 15 $(14.5 \%)$ LSCS was done.

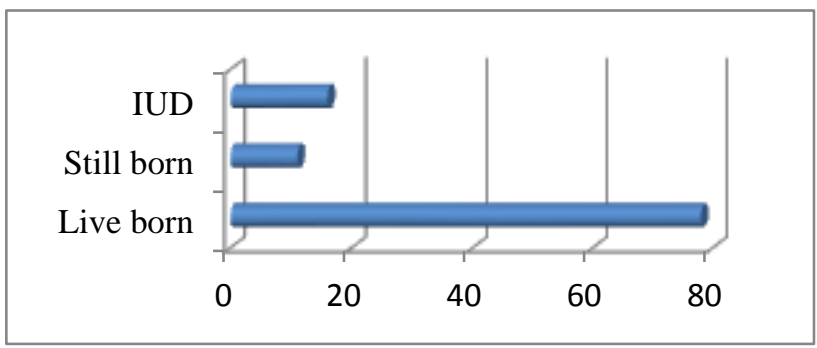

Figure 2: Shows distribution of intra uterine death, still born and live born.

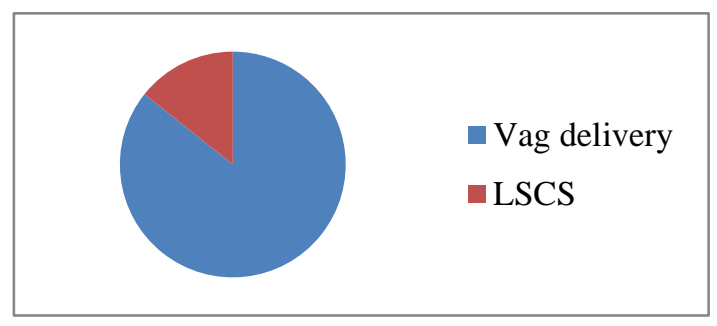

Figure 3: Relation of vaginal delivery and lower segment caesarean section.
Table 6: Maternal complications encountered.

\begin{tabular}{|lll|}
\hline Complications & $\mathbf{N}$ & $\%$ \\
\hline Abruption & 1 & 1 \\
\hline Eclampsia & 1 & 1 \\
\hline Ascites & 28 & 26.6 \\
\hline HELLP & 3 & 2.8 \\
\hline Uncontrolled BP & 5 & 4.7 \\
\hline Renal impairment & 2 & 1.9 \\
\hline Death & 0 & 0 \\
\hline
\end{tabular}

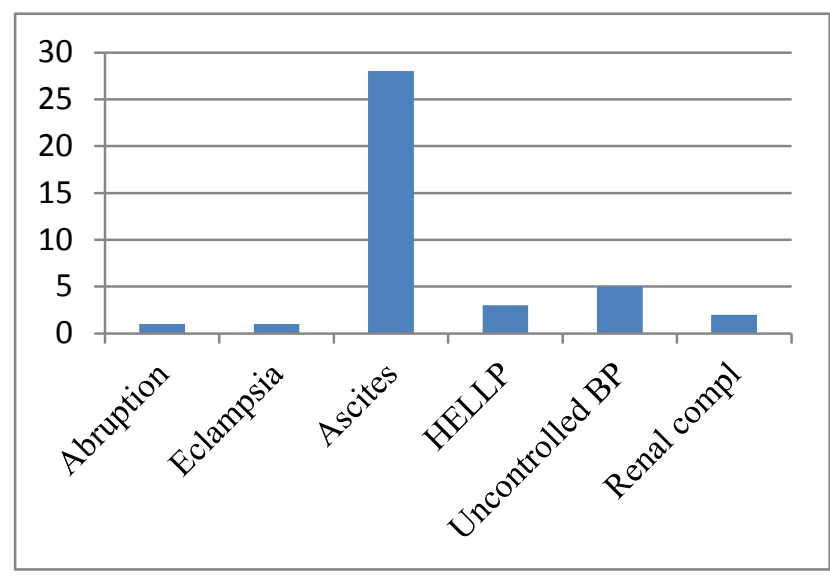

Figure 4: Distribution of maternal complications.

Table 7: Relation between complication and gestational age.

\begin{tabular}{|llllll|}
\hline Complication & $\mathbf{n}$ & $\mathbf{5 3 0}$ & $\mathbf{\%}$ & $\mathbf{\geq 3 1}$ & $\mathbf{\%}$ \\
\hline Ascites & 28 & 9 & 32 & 19 & 68 \\
\hline U/O Decreased & 2 & 1 & 50 & 1 & 50 \\
\hline Abruption & 2 & & & 2 & 100 \\
\hline Eclampsia & 1 & & & 1 & 100 \\
\hline Uncontrolled BP & 5 & 3 & 60 & 2 & 40 \\
\hline HELLP & 3 & 1 & 33.5 & 2 & 66.5 \\
\hline
\end{tabular}

From the above table it is seen that most of the complications occurs after 30 weeks of gestation. There was no death reported. When chi square test was applied this was found to be significant.

\section{DISCUSSION}

The incidence of hypertensive disorders of pregnancy is $8 \%$. These form one of the deadly triads along with hemorrhage and jaundice that result in maternal death. According to WHO severe preeclampsia accounts for $16.1 \%$ of maternal deaths in developed countries over the past 2 decades. $^{1}$ 
Table 8: Classification of hypertensive disorders in pregnancy.

\begin{tabular}{|c|c|c|}
\hline Classification & Gestational age & Definition \\
\hline $\begin{array}{l}\text { Gestational } \\
\text { hypertension }\end{array}$ & $\geq 20$ weeks & $\begin{array}{l}\mathrm{SBP}>/=140 ; \mathrm{DBP}>/=90 \\
\text { Absence of proteinuria }\end{array}$ \\
\hline Pre eclampsia & $\begin{array}{l}\geq 20 \text { weeks with } \\
\text { documented } \\
\text { normal BP } \\
\text { recording prior }\end{array}$ & $\begin{array}{l}\text { Mild Pre eclampsia } \\
\mathrm{SBP} / \mathrm{DBP}>/=140 / 90 \text { on two occasions } 6 \text { hrs apart } \\
\text { Proteinuria }>/=300 \mathrm{mg} / 24 \mathrm{hrs} \text { or } . /=1+\text { on dipstick } \\
\text { Severe Pre eclampsia } \\
\mathrm{SBP}>/=160 \mathrm{DBP}>/=110 \text { on two occasions } 6 \mathrm{hrs} \text { apart } \\
\text { Proteinuria }>/=5 \mathrm{gm} / 24 \mathrm{hr} \text { or }>/=33 \text { on } 2 \text { random samples } 4 \mathrm{hrs} \text { apart } \\
\text { End organ signs or symptoms }\end{array}$ \\
\hline $\begin{array}{l}\text { Pre eclampsia } \\
\text { superimposed } \\
\text { on } \mathrm{C} / \mathrm{C} \\
\text { hypertension }\end{array}$ & $\geq 20$ weeks & $\begin{array}{l}\text { Patient without prior proteinuria after } 20 \text { weeks of gestation } \\
\text { Patients with prior proteinuria } \\
\text { Sudden increase in proteinuria } \\
\text { Sudden increase in BP that was previously well controlled } \\
\text { Thrombocytopenia }\left(<1,00,000 \text { platelets } / \mathrm{mm}^{3}\right. \\
\text { Elevated liver function tests }\end{array}$ \\
\hline $\begin{array}{l}\mathrm{C} / \mathrm{C} \\
\text { hypertension }\end{array}$ & $<20$ weeks & $\begin{array}{l}\mathrm{SBP}>/=140 \text { or } \mathrm{DBP}>/=90 \\
\text { Absence of proteinuria }\end{array}$ \\
\hline $\begin{array}{l}\text { Transient } \\
\text { hypertension } \\
\text { of pregnancy }\end{array}$ & $\begin{array}{l}12 \text { weeks post- } \\
\text { partum }\end{array}$ & $\begin{array}{l}\text { Diagnosis of gestational hypertension during pregnancy with } \\
\text { normalization of BP by } 12 \text { weeks post-partum }\end{array}$ \\
\hline
\end{tabular}

BP: Blood pressure; DBP: Diastolic Blood pressure; SBP: Systolic blood pressure

Data from national high blood pressure education programme working group, ${ }^{2} \mathrm{ACOG}$ committee on practice bulletins

\section{Complications and management}

Severe preeclampsia (SPE) is a complex disease with a chronologically unpredictable and progressively deteriorating course. Traditional management has included expedited delivery as the ultimate cure for SPE, aimed at preventing potential end-organ effects. Serious maternal complications of SPE include eclampsia, placental abruption, DIC, renal failure, hepatic hematoma or rupture, pulmonary edema, ARDS, retinal detachment, myocardial infarction, pancreatitis, stroke, and death. The current standard of care, therefore, includes prompt delivery of patients with SPE if the disease develops at or after 34 weeks' GA. ${ }^{21}$

\section{Early onset SPE}

A clinical conundrum arises in the $0.3 \%$ of pregnancies in which SPE develops before 34 weeks' GA. ${ }^{22}$ The decision to deliver at early GA requires weighing the risks of iatrogenic prematurity against the risks of prolonging the pregnancy. Numerous authors have suggested varying degrees of expectant management to improve perinatal outcomes. This discussion involves the rationale for expectant management, ideal candidates, contraindications, indications for delivery, and recommendations regarding the mode of delivery.

\section{Rationale of expectant management}

Given the difficulty in balancing potential maternal morbidity associated with expectant management of SPE remote from term and the risks of an iatrogenic premature birth, definitive recommendations are limited by the paucity of adequately powered, randomized, controlled trials.

Table 9: Comparison of signs and symptoms of mild and severe preeclampsia.

\begin{tabular}{|lll|l|}
\hline No. & Abnormality & Mild & Severe \\
\hline 1 & Diastolic BP & $<110 \mathrm{mmHg}$ & $>110 \mathrm{mmHg}$ \\
\hline 2 & Proteinuria & Trace $1+$ & $\begin{array}{l}\text { Persistent } \\
3+\text { or more }\end{array}$ \\
\hline 3 & Headache & Absent & Present \\
\hline 4 & Visual disturbances & Absent & Present \\
\hline 5 & $\begin{array}{l}\text { Upper abdominal } \\
\text { pain }\end{array}$ & Absent & Present \\
\hline 6 & Oliguria & Absent & Present \\
\hline 7 & S. Creatinine & Normal & Elevated \\
\hline 8 & Thrombocytopenia & Absent & Present \\
\hline 9 & Hyperbilirubinemia & Absent & Present \\
\hline 10 & $\begin{array}{l}\text { Liver enzyme } \\
\text { elevation }\end{array}$ & Minimal & Marked \\
\hline 11 & IUGR & Absent & Obvious \\
\hline 12 & Pulm oedema & Absent & Present \\
\hline
\end{tabular}

Only a few randomized trials have been reported. ${ }^{20,21}$ Each study reported improved perinatal outcomes with minimal maternal morbidity. Odendaal and colleagues randomized 38 women with SPE (defined by BP criterion only) who were between 28 and 34 weeks of gestation to immediate delivery after antenatal 
corticosteroid administration $(n=20)$ or expectant management $(n=18) .^{20}$ Mean prolongation of pregnancy in the expectant management group was 7.1 days $(\mathrm{P}<0.05)$, with no increase in maternal complications.

In Sibai and associates' study of 95 patients with early onset SPE between 28 and 32 weeks (again diagnosed by BP criterion only), 46 patients were randomized to immediate delivery and 49 to expectant management. ${ }^{21}$ Mean pregnancy prolongation was 15.4 days (range, 4-36 days), with no cases of eclampsia.

In a nonrandomized study by Sibai and colleagues, 109 patients with SPE in the second trimester were followed. ${ }^{22}$ Expectant management with "aggressive" maternal and fetal surveillance was used for patients more than 24 and no more than 27 weeks' gestation $(n=84)$, and termination was recommended for those no more than 24 weeks' gestation $(n=25$, with 10 undergoing termination and 15 electing to continue the pregnancy). Expectant management resulted in mean prolongation of pregnancy of 13.2 days (range, 4-28 days). There were no differences between the 2 groups with regard to maternal complications.

The afore mentioned studies showed that expectant management with aggressive monitoring of maternal status may improve the outcome in patients with early onset SPE, but judicious selection of candidates should be employed. ${ }^{20-22}$ The ideal candidate for expectant management of preeclampsia is an appropriately counselled patient at least $24+0 / 7$ weeks' and no more than $33+6 / 7$ weeks' GA, with reassuring maternal and fetal status. ${ }^{18}$ The lower limits of viability vary among institutions $(22+0 / 7$ to $24+0 / 7$ weeks' GA). Counselling patients in the peri viable period should reflect these differences. The patient should be counselled on the likelihood of perinatal survival on the basis of GA, estimated fetal weight, gender, and individual institutional experiences, balanced against the risks of maternal complications. Candidates should be admitted to a tertiary care center with 24-hour availability of obstetricians, anesthesiologists, and a neonatal team. One study demonstrated that approximately $63 \%$ of women diagnosed with early onset SPE are eligible for expectant management using this criteria. ${ }^{9}$

In our study most of the women were primi gravida this confirms with the widely considered hallmark of pre eclampsia. The finding that among the multi gravida there were significant women who had pre eclampsia in the previous pregnancy also confirm the common finding that there is $11-12 \%$ increase in the incidence of pre eclampsia once they get pre eclampsia in the first pregnancy. The pregnancy was prolonged by 16.7 days with a median of 14.2 days.

When the gestational age was less than 25 weeks, the mean gain in prolongation of pregnancy was 10 days. Thus when the women entered into the study at early gestational age the mean number of days gained was more [11 days in study by Hall \& Odendaal (2000); 14 days in study by Pattirson et al. (1998); 10 days in study by Viser et al.].

Table 10: Mean prolongation of pregnancy in days by various studies.

\begin{tabular}{|ll|}
\hline Study & $\begin{array}{l}\text { Mean } \\
\text { prolongation } \\
\text { in days }\end{array}$ \\
\hline Index study & 16.7 \\
\hline Hall \& Odendaal & 11 \\
\hline Pattirson et al. & 14 \\
\hline Viser et al. & 10 \\
\hline
\end{tabular}

In the index study there were $38 \%$ maternal complications which is comparable to $27 \%$ in hall et al. ${ }^{23}$ The control of BP was carefully applied with 2 or 3 drugs. There was no complication like intracerebral bleed (ICB). It should be noted that ICB is one of the important cause of maternal mortality in South Africa. There were no such complications reported by Hall et al. The occurrence of HELLP syndrome $(2.8 \%)$ was lower than figure of $20 \%$ reported in the overview of HELLP. ${ }^{28}$

\section{CONCLUSIONS}

From the one year study, it was found that there was a gain of 16 days when the mother with early onset SPE was put in expectant management. The maternal complications were as per the international standards and there was no increase in mortality and morbidity of the mother. Hence it will be advantageous to put a patient with early onset severe pre eclampsia in expectant management rather than terminate the pregnancy immediately as the practice is now. But to obtain optimum outcome the selection of patients and maternal care in a tertiary care centre is preferable.

Funding: No funding sources

Conflict of interest: None declared

Ethical approval: The study was approved by the institutional ethics committee

\section{REFERENCES}

1. Report of the National High Blood Pressure Education Program Working Group on high blood pressure in pregnancy. Am J Obstet Gynecol. 2000;183(1):S1-S22.

2. ACOG Committee on Practice Bulletins-Obstetrics. ACOG practice bulletin. Diagnosis and management of preeclampsia and eclampsia. Number 33, January 2002. Obstet Gynecol. 2002 Jan;99(1):159-67.

3. Cunningham FG, Gant NF, Leveno KJ, Gilstrap LC III, Hauth JC. Hypertensive disorders in pregnancy. In: Williams Obstetrics. $21^{\text {st }}$ ed. New York: McGraw-Hill; 2001:567-618.

4. Hauth JC, Ewell MG, Levine RJ, et al. Pregnancy outcomes in healthy nulliparas who developed 
hypertension. Calcium for Preeclampsia Study Group. Obstet Gynecol. 2000;95(1):24-287.

5. Zhang J, Meikle S, Trumble A. Severe maternal morbidity associated with hypertensive disorders in pregnancy in the United States. Hypertens Pregnancy. 2003;22(2):203-12.

6. Catov JM, Ness RB, Kip KE, Olsen J. Risk of early or severe pre-eclampsia related to pre-existing conditions. Int J Epidemiol. 2007;36(2):412-9.

7. Haddad B, Deis S, Goffinet F, Paniel BJ, Cabrol D, Siba BM. Maternal and perinatal outcomes during expectant management of 239 severe preeclamptic women between 24 and 33 weeks' gestation. Am J Obstet Gynecol. 2004;190(6):1590-5.

8. Duckitt K, Harrington D. Risk factors for preeclampsia at antenatal booking: systematic review of controlled studies. BMJ. 2005;330(7491):565.

9. Sanders CL, Lucas MJ. Renal disease in pregnancy. Obstet Gynecol Clin North Am. 2001;28(3):593-600.

10. Jones DC, Hayslett JP: Outcome of pregnancy in women with moderate or severe renal insufficiency. N Engl J Med. 1996;335(4):226-32.

11. Landon MB. Diabetic nephropathy and pregnancy. Clin Obstet Gynecol. 2007;50(4):9981006.

12. Mello G, Parretti E, Gensini F et al. Maternal-fetal flow, negative events, and preeclampsia: role of ACE I/D polymorphism. Hypertension. 2003;41(4):932-7.

13. Dudding T, Heron J, Thakkinstian A, et al. Factor V Leiden is associated with pre-eclampsia but not with fetal growth restriction: a genetic association study and meta-analysis. J Thromb Haemost. 2008;6(11):1869-75.

14. Alfirevic Z, Roberts D, Martlew V. How strong is the association between maternal thrombophilia and adverse pregnancy outcome? A systematic review. Eur J Obstet Gynecol Reprod Biol. 2002;101(1):6-14.

15. Yamada N, Arinami T, Yamakawa-Kobayashi K et al. The $4 \mathrm{G} / 5 \mathrm{G}$ polymorphism of the plasminogen activator inhibitor-1 gene is associated with severe preeclampsia. J Hum Genet. 2000;45(3):138-41.

16. Eskenazi B, Fenster L, Sidney S. A multivariate analysis of risk factors for preeclampsia. JAMA. 1991;266(2):237-41.

17. Kongnyuy EJ, Nana PN, Fomulu N, Wiysonge SC, Kouam L. Doh AS. Adverse perinatal outcomes of adolescent pregnancies in Cameroon. Matern Child Health J. 2008;12(2):149-54.
18. Rijhsinghani A, Yankowitz J, Strauss RA, Kuller JA, Patil S, Williamson RA. Risk of preeclampsia in second-trimester triploid pregnancies. Obstet Gynecol. 1997;90(6):884-8.

19. Sibai BM, Barton JR. Expectant management of severe preeclampsia remote from term: patient selection, treatment, and delivery indications. Am J Obstet Gynecol. 2007;196(5):514.e1-9.

20. Gupta LM, Gaston L, Chauhan SP. Detection of fetal growth restriction with preterm severe preeclampsia: experience at two tertiary centers. Am J Perinatol. 2008;25(4):247-9.

21. Odendaal HJ, Pattinson RC, Bam R, Grove D, Kotze TJ. Aggressive or expectant management for patients with severe preeclampsia between 28-34 weeks' gestation: a randomized controlled trial. Obstet Gynecol. 1990;76(6):1070-5.

22. Sibai BM, Mercer BM, Schiff E, Friedman SA. Aggressive versus expectant management of severe preeclampsia at 28 to 32 weeks' gestation: a randomized controlled trial. Am J Obstet Gynecol. 1994;171(3):818-22.

23. Sibai BM, Akl S, Fairlie F, Moretti M. A protocol for managing severe preeclampsia in the second trimester. Am J Obstet Gynecol. 1990;163(3):733-8.

24. Hall DR, Odendaal HJ, Steyn DW, Grov D. Expectant management of early onset, severe preeclampsia: maternal outcome. BJOG. 2000;107(10):1252-7.

25. Alexander JM, Bloom SL, McIntire DD, Leveno KJ. Severe preeclampsia and the very low birth weight infant: is induction of labor harmful? Obstet Gynecol. 1999;93(4):485-8.

26. Nassar AH, Adra AM, Chakhtoura, N, G mez-Marin $\mathrm{O}$, Beydoun S. Severe preeclampsia remote from term: labor induction or elective cesarean delivery? Am J Obstet Gynecol. 1998;179(5):1210-3.

27. Alanis MC, Robinson CJ, Hulsey TC, Ebeling M, Johnson DD. Early-onset severe preeclampsia: induction of labor vs elective cesarean delivery and neonatal outcomes. Am J Obstet Gynecol. 2008;199(3):262.e1-6.

28. Pattinson RC, Odendaal HJ, Du Toit R. Conservative management of SPE before 28 weeks of gestation. S Afr Med J. 1988;73:516-8.

29. Chari RS, Friedman SA, Schiff E. Daily antenatal testing in women with severe pre eclampsia. Am J Obstet Gynecol. 1995:173:1207-10.

DOI: $10.5455 / 2320-1770 . i j r \operatorname{cog} 20140318$

Cite this article as: Viswanathan $\mathrm{M}$, Daniel S. The study of maternal outcome of early onset severe pre eclampsia with expectant management. Int $\mathbf{J}$

Reprod Contracept Obstet Gynecol 2014;3:92-7. 